\title{
Benign Prostat Hiperplazisi ve Metabolik Sendrom
}

\author{
Ahmet Hakan Haliloğlư ${ }^{1}$ Semih Tangal ${ }^{1}$
}

${ }^{1}$ Ufuk Üniversitesi, Tıp Fakültesi, Üroloji Anabilim Dalı, Ankara

\section{Giriş}

$\mathrm{M}$ etabolik sendrom dünya çapında oldukça yaygın olarak görülen, etyolojik faktörleri tam olarak ortaya konulamamış, epidemik bir durumdur. İnsülin direnci ile başlayan ve abdominal obezite, glukoz intoleransı veya diabetes mellitus (DM), dislipidemi, hipertansiyon (HT) ve koroner arter hastalığı (KAH) gibi sistemik bozuklukların birbirine eklendiği hayatı tehdit eden endokrinolojik bir bozukluktur. Nedeni ve ortaya çıkma şekilleri tam olarak açıklanamamakla birlikte, günümüzde sadece endokrinolojiyi ilgilendiren bir klinik durum olmaktan çıkmıştır(1). Insülin direnci sendromu, Reaven sendromu, CHAOS sendromu, sendrom $X$, polimetabolik sendrom, metabolik sendrom için bugüne kadar kullanılan diğer isimlerdir. Prevalansı erişkinlerde \%22 olarak bildirilmektedir. Görülme sıklı̆̆1 yaş ile birlikte artmakta, 20-29 yaş aralığında \%6.7 iken 60-69 yaş aralığında \%43.5'e yükselmektedir. Ülkemizde yapılan çalışmada, 30 yaş üzerinde 9.2 milyon kişide metabolik sendrom bulunduğu hesaplanmıştır. KAH tanısı alan hastaların \%53'ünde metabolik sendrom tanısı konulabileceği görülmüştür. Ülkemizde metabolik sendromun cinsiyete göre dağılımına bakıldığında; erkeklerin \%28'inde, kadınların $\% 40$ 'ında tanı kriterleri mevcuttur (2).

Metabolik sendromun, ürolojik hastalıklar ile ilişkisini araştıran yazılar son yıllarda giderek artan miktarda basılmaya başlanmıştır. Prostat kanseri, üriner sistem taş hastalığı, hipogonadizm, infertilite, kadın cinsel sağlığı ve erektil disfonksiyon, metabolik sendrom ile ilişkisi çalışılan ürolojik konulardır. Benzer yaş grubunu ilgilendiren hastalıklar olarak ürolojik patolojilerin ve metabolik sendromun sıklıkla birlikteliği şaşırtıcı değildir. Son yıllarda yapılan preklinik ve klinik araştırmalar, metabolik düzensizliklerin, benign prostat hiperplazisi (BPH) gelişiminde, prostat büyümesinde ve alt üriner sistem semptomlarının (AÜSS) kötüleşmesinde ciddi rolü olduğunu göstermiştir (3). Aslında konu ile ilgili ilk çalışmalar 1960'lı yıllarda yapılmış, DM ve HT ile prostat büyümesinin patogenezi arasında ilişki olduğu sunucuna varılmıştır (4).

Metabolik sendrom, insülin direnci ile başlar, abdominal obezite ile devam eder ve tabloya glukoz intoleransının eklenmesi ile DM gelişir. Zamanla dislipidemi ve HT da klinik tabloda yerini alır ve metabolik sendrom koroner arter hastalığ1 ile istenmeyen sona doğru seyrini devam ettirir.

Etyolojisine bakıldığında tek bir nedenden bahsetmek mümkün değildir. Genetik, enfeksiyöz veya çevresel faktör- ler suçlanmakla birlikte, tablo tek başna hiçbirisinin üzerine yüklenememektedir. Poligenik bir yatkınlıktan bahsetmek belkide en doğru yol olacaktır. Modern yaşam tarzının getirdiği sedanter yaşam ve buna eklenen yüksek kalorili beslenme tablonun ortaya çıkmasındaki en önemli nedendir.

Metabolik sendrom tanısı koyabilmek için;

- Diabetes Mellitus

- Bozulmuş glukoz intoleransı

- İnsülin direnci

Durumlarından en az bir tanesinin,

- HT (diastolik > $85 \mathrm{mmHg}$, sistolik >130 mmHg, veya antihipertansif kullanımı)

- Dislipidemi (Trigliserid $>150 \mathrm{mg} / \mathrm{dL}$, HDL erkek $<40 \mathrm{mg} /$ $\mathrm{dL}$, kadın $<50 \mathrm{mg} / \mathrm{dL}$ )

- Abdominal obezite (vücut kitle indeksi $>30 \mathrm{~kg} / \mathrm{m}^{2}$ veya bel çevresi: erkek $>94 \mathrm{~cm}$, kadın $>80 \mathrm{~cm}$ )

En az iki tanesinin olması gerekir.

Kabaca detaylandirmak gerekirse prostat, androjene bağımlı, üretranın etrafını saran, tübüloalveoler yapıda ekzokrin bir bezdir. Toplam ejekulatın \%30'unu salgılayan prostat, asidik içerikli bir salgıya sahiptir. Prostat büyümesi 3 fazda tamamlanır, doğuma kadar 1.5 gr boyuta ulaşan organ erken pubertede $10 \mathrm{gr}, 20$ yaşında ise 20 gr boyuta ulaşır. Prostatın büyüklüğü puberte sonrası uzun süre sabit kalır. Daha sonra prostat dokusunun büyümesi genel olarak periüretral bölgenin hacimlenmesi ile olur. Prostatın toplam büyüklüğünün \%95'ini oluşturan periferik ve santral bölgeler bu büyümeden büyük ölçüde etkilenmez. Prostat epitelyal ve fibromusküler stroma hücreleri olmak üzere iki hücre tipinden oluşur. Fibromusküler stroma, fibroblast ve düz kas hücrelerini içerir (7).

$\mathrm{BPH}$, erkeklerde en sık görülen benign hastalıktır. Yaşla birlikte insidansı artan hastalığın, görülme oranları; 4. dekatta $\% 8$ iken, 9 . dekata gelindiğinde $\% 80$ olmaktadır (8). Yıllara göre BPH görülme insidansının arttığı gösterilmiştir. 1998 yılında tüm hospitalizasyonların \%4.8'i BPH'ya bağlı iken 2008 yılında bu oranın \%8'e yükseldiği hesaplanmıştır. BPH'nın görülme oranlarının ileri yaş erkeklerde arttığı, ancak dolaşımdaki testesteronun aynı yaş aralığında azaldığ düşünüldüğünde, androjen bağımlı bir organ olan prostatın büyümesinde etkili hormonlar dişında faktörlerin de olduğu açıktır. Dolaşımdaki testesteron ile BPH gelişim hızı arasında bir ilişki gösterilememiştir (9). 
BPH ile metabolik sendrom arasındaki ilişkiyi gösteren ilk prospektif çalışma 1998 yılında Hammarsten ve ark.'ları tarafından 158 erkek üzerinde yapılmıştır. Prostat büyüklügü ile metabolik sendrom komponentleri arasındaki ilişkinin araştırıldığı çalışmada; DM, arteriyel HT, obezite, yüksek insülin seviyesi ve düşük HDL kolesterolün $\mathrm{BPH}$ için birer risk faktörü olduğu sonucuna varılmıştır. Bununla birlikte metabolik sendromun prostat hacmi ve serum prostat spesifik antijen (PSA) düzeyinin artması ve akut üriner retansiyon riski de dahil olmak üzere, BPH'nın progresyonu, AÜSS skorunun artması, idrar akış hızının düşmesi, rezidüel idrar miktarının artması ve cerrahi gereksinim için belirleyici olarak gösterilmiştir (5).

Prostat volümü ve metabolik sendrom arasındaki ilişkinin gösterilmesinin ardından, değiştirilebilir ve tedavi edilebilir durumlar olan; abdominal obezite, dislipidemi, hiperglisemi gibi faktörler ilgi çekmiştir. Bunların tedavi edilmesinin, gelişen $\mathrm{BPH}^{\prime}$ nın tedavisinde ve $\mathrm{BPH}$ gelişiminden korunmada önemli olacağı vurgulanmıştır (6).

Birçok çalışma BPH ve obezite arasında yakın ilişkiyi göstermektedir. BPH patogenezine obezitenin katkısı erken erişkinlik döneminde başlar. Vücut kitle indeksi (VKI) ile yüksek prostat hacmi ve prostat içerisinde inflamasyon arasında kesin ilişki gösterilmiştir (10). Artan VKİ seminal sivida artan IL-8 seviyesi ile, bu da prostatik inflamasyon ile ilişkili bulunmuştur. Aynı çalışma artan bel çevresinin prostat hacmi ile ilişkili olduğunu göstermiştir. Bel çevresi $109 \mathrm{~cm}$ 'in üzerinde olan erkeklerde BPH nedeni ile cerrahi tedavi ihtimali, bel çevresi 109 cm'den küçük olanlara göre $\% 38$ daha fazladır (11). BPH ile metabolik sendrom arasındaki ilişki açısından yapılan araştırmalarda, metabolik sendrom bileşenlerinin sayısı arttıkça prostat hacminin arttığı rapor edilmiştir. Bunlar içerisinde dislipidemi, $60 \mathrm{~mL}$ 'nin üzerindeki prostat hacimleri ile en çok ilişkili bileşen olarak göze çarpar. BPH'nın CD 45 ile yapılan histopatolojik incelemele- rinde, yüksek inflamatuar yanıtın eşlik ettiği görülmektedir. Metabolik sendromun, BPH ile birlikte olduğu durumlarda bu inflamatuar yanıt belirgin olarak artmaktadır. Özellikle HDL kolesterolün azalmasının bu inflamatuar yanıt ile ilişkisi kuvvetlidir. Yağlar, prostat inflamasyonu, BPH ve AÜSS gelişiminde ve ilerlemesinde rol sahibidir. Bu nedenle prostat hücreleri üzerine zararlı etkiye sahip olabilirler (12). Tavşan modellerinde yapılan çalışmada, metabolik sendromun, prostat ve mesane üzerine olan etkilerini azaltmak için verilen testesteron, hipoksi, fibrozis ve inflamasyonu azaltarak pozitif yönde etkilemektedir. Tavşan prostatlarında androjen reseptörlerinin sayısının metabolik sendrom varlığında arttığı görülmüştür (13).

$\mathrm{BPH}$ ve metabolik sendromun ortak patogenetik mekanizmasından bahsetmek gerekirse, öncelikle üriner sistemi etkileyen bazı metabolik olayları hatırlatmak gerekir: NO-cGMP seviyesinin azalması, RhoA kinaz aktivitesinin artması, otonomik hiperaktivite ve pelvik ateroskleroz; üriner sistemde korpus kavernozumları, prostatı, üretrayı, mesaneyi, etkiler ve fonksiyonel değişikliklere neden olur. Ayn bölgeleri kronik enflamasyon ve steroid hormon dengesini bozarak metabolik sendrom da etkiler ve aynı klinik durumların ortaya çıkmasına neden olur (Tablo) (14).

Park ve ark.'larının 1224 hasta üzerinde yaptıkları çalışmada, 50-59 yaş aralığındaki metabolik sendromu olan erkeklerde postmiksiyonel rezidüel idrar ve prostat volümü anlamlı olarak daha fazla bulunmuş ve bu bulgular metabolik sendromlu erkeklerde, BPH sıklığının daha fazla olduğuna kanit olarak gösterilmiştir (15).

Yapılan çalışmalar, hormonal, inflamatuar ve metabolik değişikliklerin BPH oluşumunda ve ilerlemesinde etkin role sahip olduğunu göstermiştir. Metabolik sendrom ve özellikle dislipidemi ve hiperinsülinemi başta olmak üzere, artan bel çevresi ile birlikte, prostat içerisinde inflamasyonu arttırabilir. Androjen eksikliği veya relatif hiperöstrojenizmin

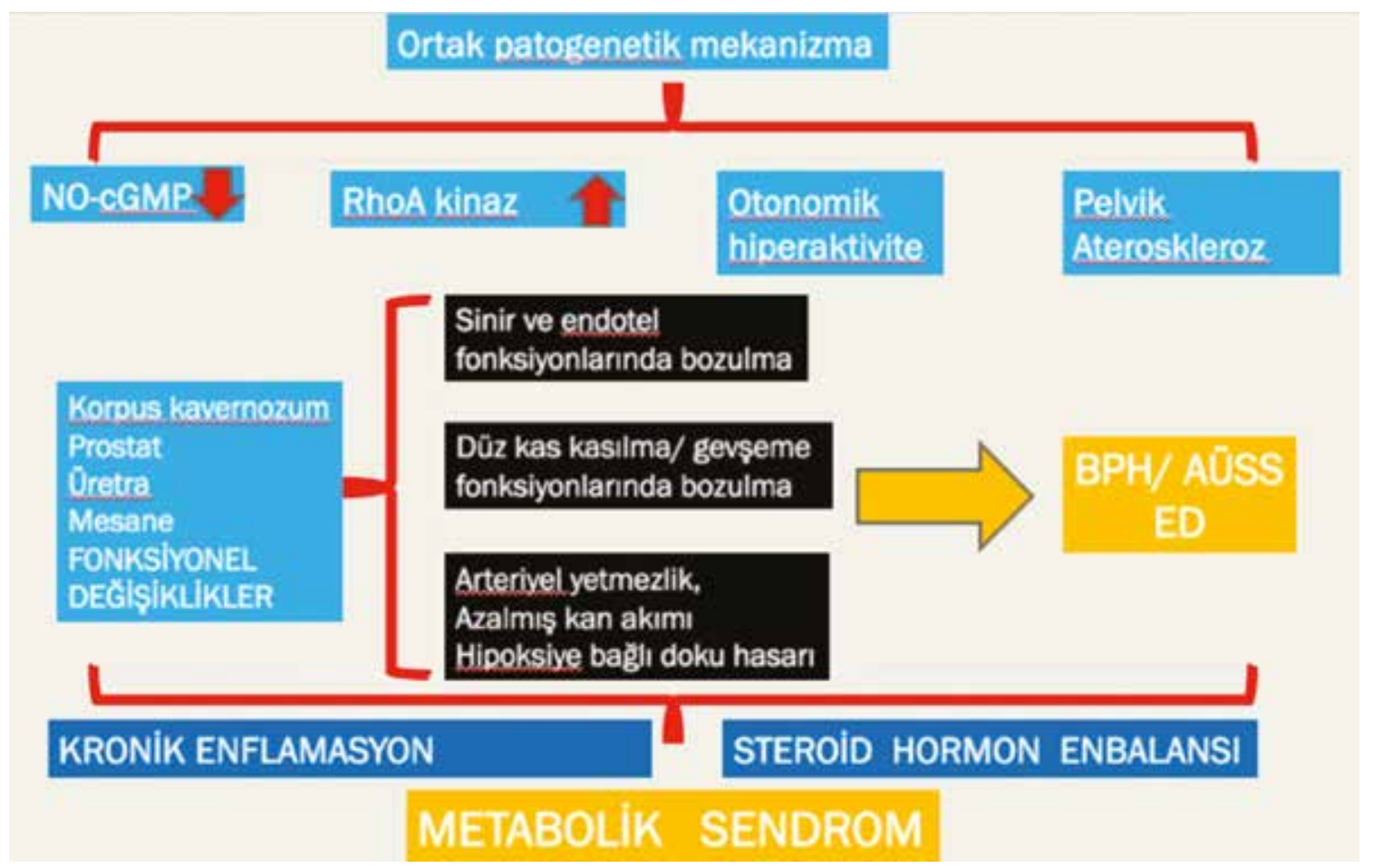

Tablo: BPH/AÜSS ve Metabolik Sendrom ortak patogenetik mekanizması 
etkilerini belirginleştirebilir. Subklinik veya klinik, bakteriyel veya viral bir enfeksiyonun prostatta başlattığı inflamasyon BPH/ AÜSS gelişiminin ilk adımı olabilir. Dislipidemi DM, obezite gibi metabolik sendrom bileşenleri bu inflamasyonun ikinci adımını oluşturabilir. Ardından veya beraberinde gelişen hipogonadizm ve/veya hiperöstrojenizm ile son adım tamamlanarak, BPH/AÜSS gelişebilir.

Tüm bu verilerin 1şı̆̆ında, metabolik sendroma karşı alınacak önlemler ve gerekli tedaviler, BPH/AÜSS gelişmeden veya ilerlemeden etkin bir tedavi imkanı sunacaktır. Belkide sadece yaşam tarzı değişiklikleri, erkekleri ilerleyen yaşlardaki AÜSS'dan koruyabilir.

\section{Kaynaklar}

1. Isra A, Khurana L. Obesity and the metabolic syndrome in developing countries. J Clin Endocrinol Metab 2008;93:930

2. Satman I, Yılmaz T, Sengül A. Population- based study of diabetes and risk characteristics in Turkey: results of the Turkish diabetes epidemiology study (TURDEP). Diabetes Care. 2002;25:1551-6

3. De Nunzio C, Aronson W, Freedland SJ, Giovannucci E, Parsons JK. The correlation between metabolic syndrome and prostatic diseases. Eur Urol 2012; 61:560-70

4. Nandeesha H, Koner BC, Dorairajan LN, Sen SK. Hyperinsulinemia and dyslipidemia in non-diabetic benign prostatic hyperplasia. Clin Chim Acta 2006;370:8993

5. Hammarsten J, Hogstedt B, Holthuis N. Components of the metabolic syndrome-risk factorsfor the development of benign prostatic hyperplasia. Prostate cancer Prostatic Dis 1998;1:157-62

6. Parsons JK. Modifiable risk factors for benign prostatic hyperplasia and lower urinary tract symptoms: new approaches to old problems. J Urol 2007; 178: 395-401
7. Vignozzi L, Rastrelli G, Corona G, Gacci M, Forti G, Maggi M. Benign prostatic hyperplasia: a new metabolic disease ? J Endocrinol Invest 2014;37:313-322

8. Zou C, Gong D, Fang N, Fan Y. Meta- analysis of metabolic syndrome and benign prostatic hyperplasia in Chinese patients. World J Urol 2016; 34(2):281-9

9. Corona G, Vignozzi L, Rastrelli G, Lotti F, Cipriani S, Maggi M. Benign Prostatic hyperplasia: a new metabolic disease of the aging male and its correlation with sexual dysfunctions. Int J Endocrinol 2014; 13

10. Wang S, Mao Q, Lin Y.Body mass index and risk of BPH: a meta-analysis. Prostate Cancer Prostatic Dis 2012;15:265-272

11. Giovannucci E, Rimm EB, Liu Y. Body mass index and risk of prostate cancer in U.S. health professionals. J Natl Cancer Inst 2003;95:1240-1244

12. Lotti F, Corona G, Vignozzi L, Rossi M, Maseroli E, Cipriani S, Gacci M, Forti G, Maggi M. Metabolic syndrome and prostate abnormalities in male subjects of infertile couples. Asian J Androl 2014;16(2):295-304

13. Vignozzi L, Morelli A, Sarchielli E. Testosterone protects from metabolic syndrome-associated prostate inflammation: an experimental study in rabbit. J Endocrinol 2012; 212:71-84

14. Andersson KE. Neurourology and urodynamics. Neurourol Urodyn 2011;30(7):1207.

15. Park YW, Kim SB, Kwon H. The relationship between lower urinary tract symptoms/ benign prostatic hyperplasia and the number of components of metabolic syndrome. Urology 2013;82:674-679.

Yazışma Adresi:

Ahmet Hakan Haliloğlu,

Ufuk Üniversitesi, Tıp Fakültesi, Üroloji Anabilim Dalı, Ankara

Tel: +905054764416

e-mail:ahmethakan75@yahoo.com 